\title{
A Changing Landscape of Intimacy: The Case of a Single Mother by Choice
}

\author{
by Linda L. Layne

\section{Colorado School of Mines}

Sociological Research Online, 20 (4), 7

<http://www.socresonline.org.uk/20/4/7.html>

DOI: $10.5153 /$ sro.3739

Received: 7 Dec 2014 | Accepted: 22 Jun 2015 | Published: 30 Nov 2015

\begin{abstract}
American women who purposely undertake motherhood without the involvement of a male partner tend to be beneficiaries of secondwave feminist achievements in the areas of expanded educational and employment opportunities. I draw on an in-depth, longitudinal case study of one such Single Mother by Choice (SMC) to explore how the opportunities she has enjoyed and professional achievements she has attained have shaped her 'intimate landscape.' Intimacy means 'innermost,' and refers to a spatial relationship, whether physical and or metaphorical. 'Landscape' refers to 'all the visible features of an area' and 'the distinctive features of a particular situation or intellectual activity.' Together Carmen and I engaged in topography, producing a detailed description of the arrangement of the features of this area of her life-the intimate physical and emotional relations with her children, her dog, her mother, and close emotional relationships with her siblings and their families, some friends, and members of her church.
\end{abstract}

Keywords: intimacy, single mothers by choice, sex, landscape, friendship, pets, children, nudity, co-sleeping, siblings, church, eldercare

1.1 Writing in 1992, in the introduction to his much-cited The Transformation of Intimacy, Giddens declares that 'today, for the first time in history, women claim equality with men' and through their pioneering exploration of relationships 'of sexual and emotional equality' they have brought about great changes in 'forms of gender power.' Since then, a number of scholars have challenged his assertion that 'a more profound equality between men and women is emerging' through the ascendancy of a type of intimacy premised on 'a transactional negotiation of personal ties by equals' (Giddens 1992:3). Much subsequent empirical research (e.g., Budgeon 2006, Gray 2006, Macvarish 2006, Roseneil 2006) depicts 'a much messier and less optimistic picture' (Jamieson 1999:489). For instance, Jamieson (1999:477) argues that 'intimacy exists between many heterosexual couples despite gender inequality,' rather than because of its demise.

1.2 The case of single mothers by choice (SMCs), tells a rather more optimistic story. Here increased gender equality, resulting from public policy, not interpersonal negotiation, is leading not to greater heterosexual intimacy but to the ability to opt out of it, at least during the child-rearing years, and to concentrate instead on forging and maintaining intimate relations with others-most especially, but by no means exclusively, with children.

1.3 Of course, this is by not true for all single mothers. Many, perhaps most, are not single by choice and poor women who choose children over marriage (Edin and Kefalas 2007) do so from a very different set of opportunities and constraints. Like other scholars of SMCs (Bock 2000, Drexler 2005, Graham 2012, 2014a, 2014b, Hertz 2006, Jadva et al. 2009,Murray and Golombok 2005a, 2005b), I use the phrase 'single mothers by choice' to refer to the types of women who are members of SMC organizations - i.e., generally over 35, highlyeducated, financially-stable, who choose to build a family without a 'daddy' and do so mostly through the use of purchased sperm. 
I respond to Faircloth and Twamley's fascinating question, 'Gender, Equality and Intimacy: uncomfortable bedfellows?' by means of the in-depth case study I am undertaking with Carmen[1], an American I met in 2005 when she rented a room in my house. The next year she bought a house nearby and started a family at the age of 41 . Conceived with sperm from the same anonymous donor; Maria, now age 7 , and the fiveyear old twins, Toby and Nel, are my godchildren and those of my intimate partner. While they were living nearby, we celebrated birthdays and holidays together and regularly met after work to walk our dogs and enjoy each other's company while the children played. When she had to move for work, we decided to undertake this collaborative project as a means of supplementing our now too infrequent visits. I bought her three-unit brownstone and she bought my minivan and moved to a college town in the Midwest where, in addition to the children, she also periodically houses her 86-year old mother and a changing coterie of pets - her dog, my dog, her brother's dog, and a cat (pictured).

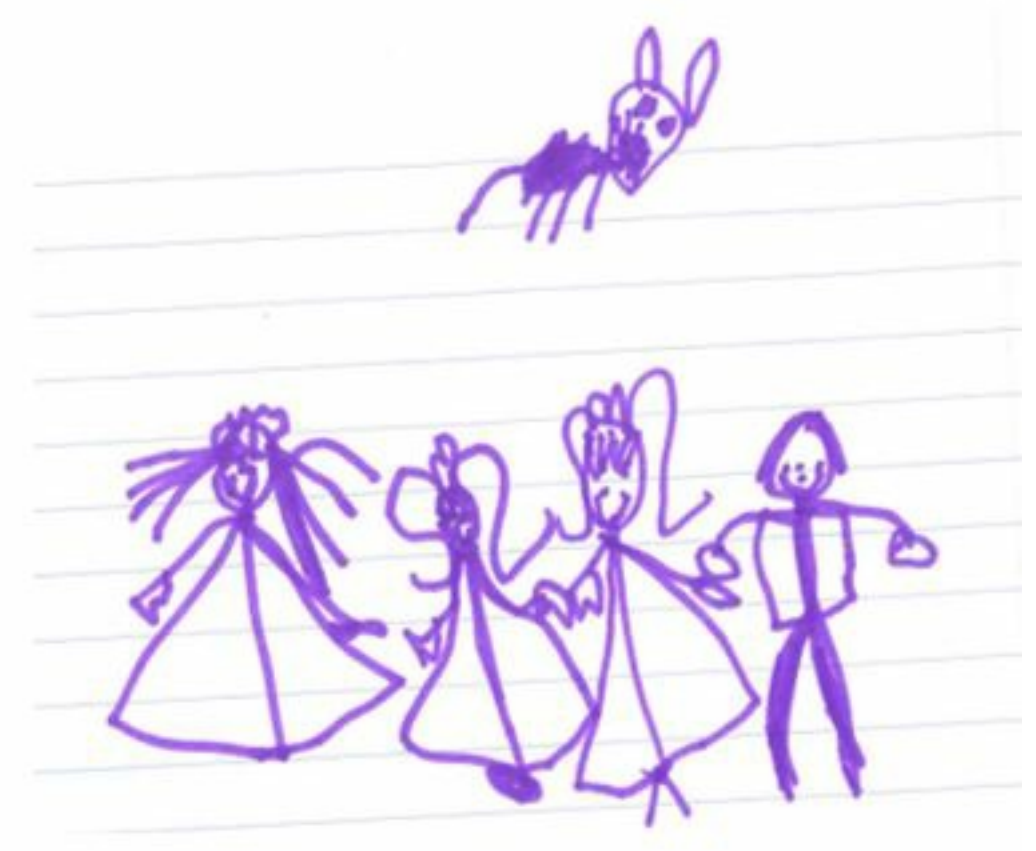

Figure 1. Family portrait including the cat, Linus, by Nel, age 4

1.5 My previous articles on Carmen focus on how the ideology of intensive mothering informs her experience $(2013,2014)$. Here I explore how the educational and professional achievements Carmen has attained, thanks in part to public policies that resulted in greater gender equality, have shaped her intimate landscape. I argue that SMCs can be counted as one of the achievements of second-wave feminism. Although SMCs have existed 'for a very long time' (Richards 2014), before the 1980s, they had not done so in such large numbers, nor with such a degree of social visibility and acceptance as to have organizations eg., Choice Moms founded in 1999, Single Mothers by Choice founded in 1982, how-to manuals (Mattes 1994, Morrisette 2008, Stonesifer 1994), published memoirs and documentaries (Askowitz 2008, Fishel 2010, Rudavsky and Katz 2000, Sloan 2007, Soseth 2008,), and social-scientific studies (Drexler 2005, Graham 2012, 2014a,b, Hertz 2006, Jadva et al. 2009, Layne 2010, 2013a, 2013b, 2014, Layne and Graham 2013, Murray and Golombok 2005a, 2005b) devoted to them.

\section{Gender and Equality}

1.6 I begin by situating Carmen's intimate landscape in terms of 'gender and equality,' the first two components of the framing question 'Gender, equality and intimacy: uncomfortable bedfellows?' Carmen is, like most American SMCs, professionally employed. The SMC website describes SMCs as 'teachers, lawyers, businesswomen, doctors, engineers, psychologists, botanists, etc.'), each of whom has 'the emotional and financial resources to support herself and her child.' The growth in the number of American women professionally employed can attributed in part to second wave feminism's achievements in reducing sex discrimination in education. Title IX, an amendment made in 1972 to the US Civil Rights Act of 1964, prohibited sex discrimination in all education programs receiving federal financial assistance. At the time the bill was passed, only 18 percent of female high school graduates were completing college compared to 26 percent of their male peers (Title IX 1997:1). By 1988, more women than men were earning associate's, bachelor's, and master's degrees and by 
Carmen grew up poor. After her parents divorced when she was 13, her mother supported the family of five on her social worker's salary, which never exceeded $\$ 47,000$ a year, and by renting a room to a boarder. Carmen recalls, with some pride, that she clothed herself from that time onward, doing seasonal farm work, babysitting, waitressing, etc. Other 1960s and 70s reforms aimed at making the US a more equalitarian society, enabled her to go to college. Title IV, another of the amendments made to the US Civil Rights Act, extended federal programs to help to low income students attend college. The scholarship program (Pell Grants) and low interest student loan program (Perkins) were named after Democratic legislators who championed these causes. In the early 1980s, Carmen got both a Pell grant and a Perkins student loan which allowed her to attend a prestigious private liberal arts college that had been all-male until the early 1970s. There she played a sport that until Title IX had been a male preserve, [2] and majored in science. She earned her Master of Science degree in the early 90s at an Ivy League College that had started accepting women in the mid-70s; and her Ph.D. in the late 1990 s, by which point about $22.2 \%$ of doctorates in the physical sciences were being awarded to women (up from 6.6\% the year Title IX was passed) (NSF 2013: table 14,NSF 2014).

Second-wave feminists also had notable successes in opening employment opportunities for women. Among the most significant legal victories of the movement were the Equal Pay Act of 1963; Executive Orders in 1965 and 1967 extending Affirmative Action rights to women. Along with higher education has come greater earning power. According to the American Association of University Women (2015:1), the decrease in the wage gap between men and women from $57 \%$ of what men earn in 1973 to $78 \%$ in 2013 is 'due largely to women's progress in education and workforce participation.' Since completing her Ph.D., Carmen has had well-paying jobs as a faculty member and as a manager in an engineering firm. Although women in the US still suffer a significant wage gap, the fact remains that thanks to second-wave successes in creating opportunities for women in higher education and the skilled labor force, significantly more women now feel they can afford to bring up children on their own. Being able to do so is a major factor in SMCs' decisions to go it alone (Mattes 1994, Morrisette 2008), and no doubt accounts, at least partly, for the fact that in the US, the number of 'never-married mothers with graduate or professional degrees' doubled between 1982 and 1992 (Abrams 1994:114).

\section{The Ethnographic Case Study - A Method for Refining Theoretical Understandings of Intimacy}

2.1 We turn now to the third and final element of the framing question, 'intimacy,' and why the in-depth, ethnographic case study method is particularly well suited for such a study. Anthropology's primary method is 'extended and, by the standards of most other social sciences, extraordinarily intimate encounters' (Coleman 2009:113). In their edited collection, Being There: The Fieldwork Encounter and the Making of Truth, Bomeman and Hamoudi champion ethnographic, 'experience-based fieldwork' as a method to 'authorize socially significant and accurate accounts' noting that 'intimate acquaintances and mutual investments...over time... make possible ... a deeper understanding' $(2009: 7,14)$.

2.2 In anthropology, ethnographic case studies have become less common as more anthropologists adopt multi-sited fieldwork. Notable case studies include Radin's Crashing Thunder: The Autobiography of an American Indian (1926), Simmons' Sun Chief: The Autobiography of a Hopi Indian (1942), Smith's Baba of Karo: A Woman of the Muslim Hausa (1954), Mintz's Worker in the Cane: A Puerto Rican Life History(1975), Shostak's Nisa: The Life and Words of a !Kung Woman (1983), Crapanzano's (1985) portrait of Tuhami, an illiterate Moroccan tile maker, and Behar's Translated Woman (1993), the story of a Mexican street peddler. My relationship with Carmen has some similarities with these cases (e.g., Simmons and Behar became fictive kin with their interlocutors, as I have done), but clearly differs in that my subject is not a marginalized individual from a foreign land, but a member of my own privileged subculture.

2.3 As far as I know, mine is the first ethnographic case study in the area of new reproductive technologies. This approach complements the more common methods (clinic ethnographies, semi-structured interviews, questionnaires, textual analyses) and offers a unique contribution to the anthropological, sociological, and historical literatures on reproductive technologies and the emergent family forms they help create.

2.4 As with other forms of qualitative research, no claims of representativeness can be made. As one reviewer of this article pointed out, 'the value' of qualitative work 'lies in helping us understand how people make sense of their worlds.' Because of our close personal relationship, the advantages and limitations of such a study may also be compared to those of autoethnography (Layne 1996). Perhaps our closeness means I lack the necessary distance to be critical; but our close friendship and fictive kin relation also means that the breadth and 
depth of my knowledge about this family permits a richer, thicker, more complete, more accurate, more nuanced account. This is particularly true when it comes to the topic of intimacy. The sharing we have done in the process of working on this piece via four skype interviews and many email exchanges has increased our intimacy in precisely the way Giddens (1992) posited as the norm in late modernity; what Jamieson calls 'disclosing intimacy,' one produced 'through a dialogue of mutual self-disclosure between equals, revealing inner qualities and feelings, simultaneously generating a self-reinforcing narration of the self' (2011: 1.5). The kind of trust and mutual knowledge Carmen and I share provides a unique place from and through which to innovate theoretical approaches to understanding and representing intimacy.

2.5 In recent years, the concept of intimacy has been taken up by a variety of scholars. In anthropology, it has come to serve as an alternate concept to 'kinship' when thinking about the social relationships which form through bonding and moral obligation (Bodenhorn nd). For other anthropologists and geographers, intimacy signals not only 'emotional relationships with others (love, solidarity), but also 'the politics of close proximity (breathing, eating, toxins, viruses, exchanging fluids)' (Jackson 2013, Weston 2012). Although intimacy has conventionally been associated with positive affect, much of the recent scholarship has found (or attributed) negative affect to intimacy. For some, the focus is on the consequences of 'unwanted intimacy'. For example, Weston's (2012) essay on food contamination post Fukishima or Walvin's 2013) history of the Atlantic slave trade which vividly conveys the 'filth and intimacy' of slave decks (2012:70). Others have shown that close attachments can be sources of ambivalence and pain (Berlant 1998:282).

2.6 In this essay, I probe the spatial dimensions inherent in the concept of intimacy by focusing on the trope of a 'landscape of intimacy.' 'Landscape' refers to 'all the visible features of an area' and 'the distinctive features of a particular situation or intellectual activity.' Carmen and I describe the collaborative method we used in producing this essay as topography. Together we produced a detailed description of the arrangement of the features of her life, with special emphasis on the relations among its components. To some, 'intimacy' connotes a minute, contained, world of private life; the opposite of 'landscape,' which signals vast, open, undelimited public spaces. Yet, I argue, 'landscape' is a particulary fruitful for thinking about intimacy. The word intimacy, literally means 'innermost,' thus, by definition, it refers to a spatial relationship.

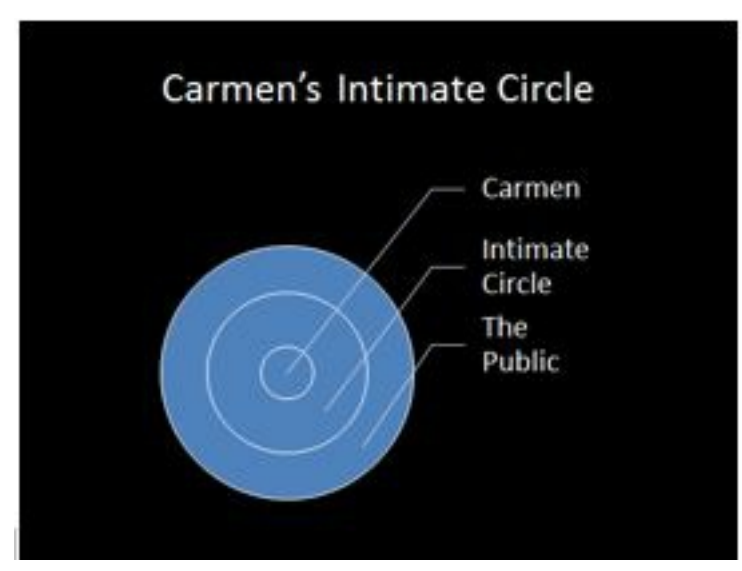

Figure 2. The image of concentric circles is one way of graphically representing intimacy.

2.7 If depicted by concentric circles, Carmen would be placed surrounded by those in her intimate circle (which maps on fairly well to her home-it includes her children, pets, natal family, and those friends from work or church whom she trusts enough to invite into her home.) Beyond this intimate circle lie others with whom she has relationships of a more formal/distant kind. The problem with this type of representation is that the boundaries between the circles appear to be static and clear; it does not convey the dynamism of an intimate landscape over time. During the time I have known Carmen, some people have moved in and others have moved out of her intimate circle. For example, she had a falling out with the unmarried brother she had lived with before moving in with me, and as a result her relationship with her mother cooled. After a couple of years of distance (including a lawsuit), the siblings repaired their relationship and Carmen's closeness with her mother was reestablished.

2.8 Kandinsky's frequently reproduced 1913 painting 'Color Study: Squares with Concentric Circles' (http://www.wassilykandinsky.net/work-370.php) which consists of multiple, colorful, irregular concentric circles arranged into a pleasing pattern, does a better job of capturing the vibrancy and complexity of Carmen's intimate 
life. [3] Despite these affordances, this painting is two dimensional and presents a static, snapshot image; as a visual metaphor it does not convey how relationships change over time. A more dynamic representation is needed.

Here is where the trope of 'landscape' has advantages. 'Landscape,' in both senses of the term, shaped land and portraits thereof, always implies a point-of-view. Abstract images like concentric circles work as tropes of intimacy from a god's-eye view; landscape paintings tend to be from a person's perspective.

2.10 Furthermore, landscapes are creations; whether actual landscapes or painters' renditions, nature is acted upon and altered by human volition and effort. Carmen's intimate landscape, and our collaborative portrayal thereof, also reflect the dynamic interplay of material/natural/volitional pushes and pulls, choices and constraints.

2.11 The term 'landscape' entered the English language from the Dutch at the end of the sixteenth century (Schama 1995:10). Schama points out that 'the Dutch term, landschap...signified a unit of human occupation..., as much as [an] object of depiction' (1995:10) and sees it as no accident 'that in the Netherlandish flood-fields, itself the site of formidable human engineering, a community developed the idea of a landschap' (1995:11).

2.12 Not only does landscape signify the shaping of spatial arrangements by humans; landscape paintings are clearly human constructions. Hockney's series of Yorkshire landscapes, especially those which depict the same location at different times of year (e.g. 'Woldgate Woods' series of 2006, the 'Three Trees near Thixendale' series of 2007, or the 'Bigger Trees Nearer Warter' of 2008), convey both the continuities and changes of a landscape over the course of time-'leaves come and go, crops grow, the autumn fields are tilled. Green hills turn blue in winter, under milky skies' (Searle 2012) - or in Carmen's case- a cat is adopted and then runs away, the winter is too cold for the old dog and she is put down, an old boyfriend reappears on the scene.

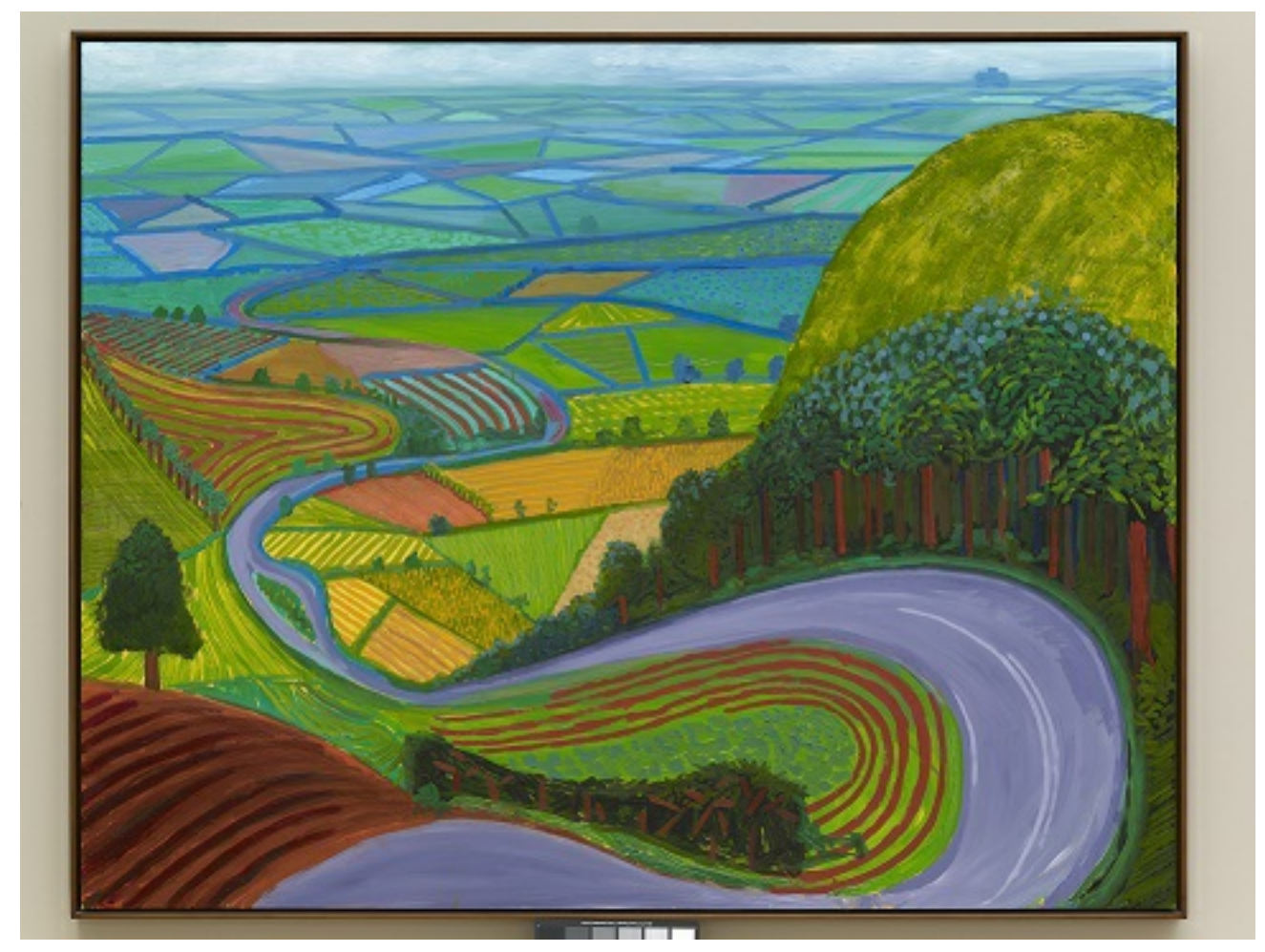

Figure 3. David Hockney, 'Garrowby Hill' (1998) oil on canvas, reproduced with permission. 


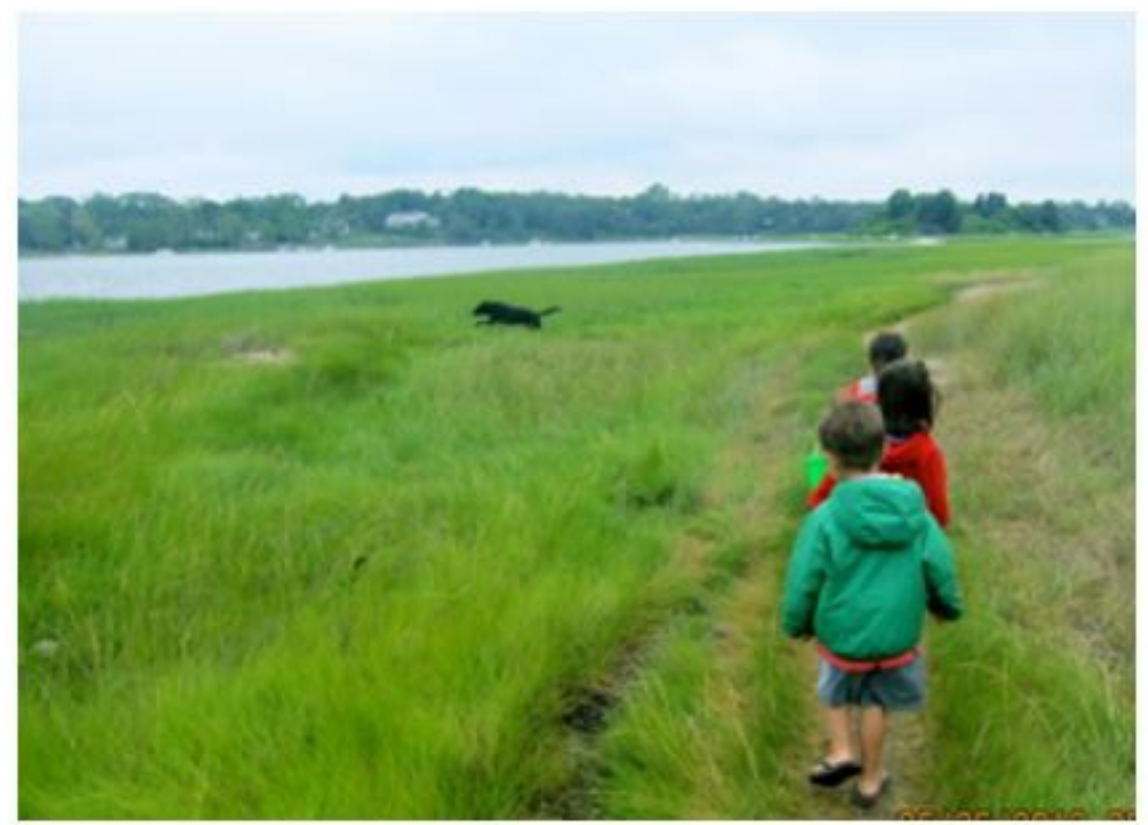

Figure 4. Maria, Nel, Toby, and beloved dog, Posy, summer 2012, photograph provided by Carmen

2.13 After studying Carmen's intimate landscape, I conclude that the landscapes that are most apt for graphically representing it are those like Hockney's paintings of a country road as it winds its way through distinctive natural and human-made features - a patch-work of fields of different sizes, shapes, colors and textures; farm houses and barns, copses of trees-until disappearing into the horizon, off into an unknown but promising future.

2.14 The point of view from the crest of the hill is that of the painter's or metaphorically that of Carmen and those who stand beside her in order to try to take in how things appear to her. The forward descent of the road suggests that Carmen (and the painter) have already traveled some distance to reach this point. If/when they move forward, their perspective will change and change and change again.

\section{Carmen's Intimate Landscape}

\section{Heterosexual intimacy}

3.1 When I introduced the subject of intimacy, Carmen assumed I meant 'sex.' It is not surprising that she would think so. Although the earliest usage of the term described the confidences of male homosociality, by the $19^{\text {th }}$ century, 'intimacy' had come to be used primarily to refer to hetero-sexual intimacy, especially the passionate, illicit kind.

3.2 As an adult, Carmen was sexually active and enjoyed two long- term relationships with men before deciding to pursue motherhood alone. This is a characteristic she shares with the majority of SMCs.[4]

3.3 The boyfriend she had during graduate school 'was from immigrant parents too.' He would often say, 'there is just a natural intimacy between us.' Carmen described it is as 'a natural, soulful, ...deeper human connection ... If I hadn't had that level of exchange with a man, I would doubt its existence.' She wonders sometimes whether she could have a relationship like that now but concludes she could not. 'I would need to take time away from my children, or my other priority-commitment, my job, ....and I'm not willing to do that.'

3.4 Carmen told me about renewing a sexual relationship with her old boyfriend, Ray, when he came to visit shortly after she'd stopped nursing. After that visit, they resumed daily phone sex, something that had been a staple of their earlier relationship because they had never lived in the same city, though they had visited each other regularly. She explained that she and Ray had met online while she was abroad and then when she came to the States: 'we took off like a rocket together.' They were together four years, broke up, then almost got back together after she'd had the children. He was open to being a step-dad, having been raised by a beloved stepdad himself, but 'when it became clear that neither of us were going to move to be with the other', they quit phoning. Because they had had such a 'nice time sexually,' Carmen is surprised she doesn't miss it. She was 
jealous when he found a girlfriend and then 'just did what you have to do, the cold turkey thing. Then I stopped thinking about it.'

She had a tubal ligation after the twin's birth, 'just as a pre-emptive measure, in case I had a sexual partner in the future.' She'd recently spotted 'a very attractive' man on the faculty.

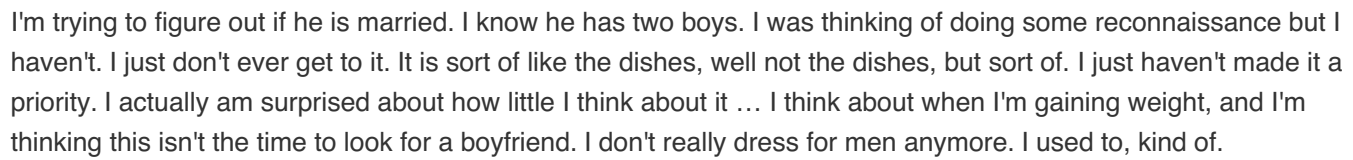

She noted that the loss of feeling sexually attractive is common for mothers regardless of their marital status. Her SMC friend, Norma, thinks it would be nice to have a man to retire with, and Carmen agrees. She imagines

\footnotetext{
the man would be post-libido. You know what, maybe it's just me but I hate that pressure from a man... 'I have this urge or desire and I look to you to fulfill it and even if you are not into it, that's what we are doing.' I hate that... but I realize it may be part of the deal in a relationship...I just don't want that pressure, especially negotiating three children in the mix.[5]
}

3.7 I shared the findings of Bianchi et al.'s study (2006) of changes in how married women, married men, and single women in the US spend their time. Carmen was not surprised to learn that married mothers are spending significantly less time with their spouses now than they did in 1975 (26\% less in 2000 than in 1975). She observed, 'There is this negotiation between spouses... you know, 'You watch the kids,' or 'You babysit while I go do something." She told me how she had been commiserating with another soccer mom about the early hour of practice on Saturdays. Later, the woman's husband arrived, came up behind his wife and started rubbing her neck. Carmen reacted strongly:

\footnotetext{
I don't know if it was me cynically thinking this or whether I was jealous or what, but [she interpreted this as], 'Thank you for bringing our kids to the soccer game so early so I could sleep late.' It wasn't 'I love you and I feel like touching you, '... I think intimacy and married life are fraught with that kind of negotiation even in the bedroom. I would hate that.
}

3.8 Carmen is also happy not to have to negotiate things, for example, to which ballet school to send her daughters (Layne 2014). In a review essay on recent books about 'women at the top,' Angell observes that one of the most notable differences between how she raised her children, and how her children are raising theirs, is that now both parents are often 'involved in decisions that look unimportant to me, and it takes on the character of a staff meeting' (2014:20). One of the books she reviewed, All Joy and No Fun: The Paradox of Modern Parenthood, reports that among middle-class parents, 'children generate more arguments than any other subject, including the venerable money, in-laws, and sex' (Angel 2014:20).

\section{Intimacy with children}

3.9 Carmen believes that one reason she doesn't 'think about men much' is because of the 'very affectionate relationship' she has with her kids. 'That may sound screwed up, you know, but I'm very physical with them.'

3.10 She reported that after visiting the children's uncles, Maria started crying and asked 'What is going to happen if you get sick and ... die?' This is a topic they have discussed before so Carmen said, 'You know what will happen. Uncle M or one of your other uncles will take care of you.' Maria replied, 'But then who is going to hug us? They don't hug us or kiss us and sleep together and snuggle. We won't have any of that.' Carmen concurs, 'She is right, you know, we have a lot of that. It is the best part of my life and evidently theirs.'

3.11 Bianchi et al. found that single mothers reported more daily positive interactions with their children (praising them, hugging or kissing them) than did married mothers or fathers (2006:81). Not surprisingly, given this, single mothers also reported the highest levels of enjoyment in caring for their children (2006:82).

3.12 I told Carmen that Bianchi et al. had also found that children living in two-parent families get double the hours of parental interaction than children in single-mother families (6 hours per week v 3) (2006:82). Carmen countered, that her engagement with her children is more intense than that of many of the married parents she observes. 
watch the lesson. Toby is waving to me from soccer practice. He wants me there. That's interaction, that's attention.

3.13 She added that if you counted the hours she spends co-sleeping with her children, she spends more hours with them than married parents do

Co-sleeping is very different as a single parent than it is with two parents who maintain the marital bed, which I don't have to deal with. It is a big thing in our family - Whose turn is it to sleep with mommy? It isn't just sleeping with me, because we read books one-on-one, we talk about the day. They take turns, so everyone gets that one-on-one mommy-time...every day. They are snuggling overnight. That is what I thought of as a defence.

3.14 She says she knows co-sleeping will have to come to an end 'because I don't think it's healthy for them to need' it. That is why she has started having them take turns, so that the other two can deal with going to sleep on their own. 'I know I will miss it, but I know it is something that I need to do for their sake.' Carmen speculated that 'if I didn't have that [physical intimacy with the children], maybe I'd be thinking more about men.'

3.15 Carmen also introduced the subject of nudity. She explained that she had grown up in a

'no nudity home.' I was one of those kids that went into the toilet stalls to change into my gym clothes, because I was less mature than my peers and darker skinned and I didn't want any observation.

Her attitude towards nudity changed as a result of a relationship with a European man during graduate school. He was divorced and had two daughters, ages 9 and 10, 'and he was always walking around nude.' She found it 'shocking' and asked why he did that, he said,

'What is with you Americans? What is the big deal? There is nothing wrong. This is what men's bodies look like. I want my children to know that.' After a while that really made sense to me, so I decided I was going to do that.

She told me about a Japanese anime film series which she checks out from the library

They are so family friendly and they have family baths in the home in a huge tub in the kitchen, and there was a single dad raising two girls because the mother was in the hospital and they all took a bath together. He was naked, lounging, and the kids were splashing around, and I remember thinking, 'That is beautiful. That's how it should be.' I have resumed bathing with my kids. That is very intimate.

3.17 She makes a distinction between what is allowable in this intimate family circle and what is allowable in the presence of others.

We are very careful, if there are visitors, we never wear our underwear. We always have to put clothes on. If we are at the gym, or changing bathing suits at the pool we will hold a towel...

She contrasts this with the intimacy they enjoy at home when it is just the four of them together and adds, if I had a boyfriend in the home that dynamic would change radically. No way would I accept nudity from him and I would not walk around nude in front of anybody then. I don't want my kids to observe him observing me nude, right, and I don't want to be observed nude by anyone except my kids.

Nudity also factors into her changing intimate relationship with her mother who now needs help getting into the tub. Until her mother was 85 , Carmen had not seen her naked. 'That would not be comfortable with a boyfriend or even a new spouse in the home.'

3.18 One definition of intimacy has to do with the exchange of bodily fluids. Carmen breastfed longer than the norm in the US -14 months with Maria, and 30 months with the twins, something she credits to the fact that she did not have a husband sharing her bed and making demands on her breasts.

\section{Intimacy with Pets[6]}

3.19 When Carmen came to my house for the first time, while considering renting my guest room, she brought along her mother and her dog to check me and the place out. Luckily, her dog immediately hit it off with my dog and her mother approved of the arrangement too. Carmen had a very intimate relationship with Posy. She explained that she and former boyfriend Ray had thought of pet ownership as a stage towards childrearing. She tried a house plant first, then a cat, who was a huge success, and so together they adopted Posy and referred to her as their child. When they broke up, Carmen insisted on keeping both the dog and cat. Posy was hugely important to Carmen-'She was combination shrink, personal trainer, best friend, and protector. I had a lot of change in my life, moved 5 times during those years, and she was my constant. I would talk to her about everything. She would structure my day.' Carmen also described her as 'my social vehicle. I went every day to the dog park with her rain or shine and made friends there that were not associated with my work life. I didn't feel lonely.' 
3.20 She 'felt guilty' when she had children because 'that whole daily routine that had revolved around her now centered around the children. Posy got less attention, less exercise.' I recalled how physically intimate she and Posy had been, how she would lean against Posy like a pillow on the floor in front of my bed when they would come up to watch a movie in my bedroom. She said yes, but that she never allowed Posy on the bed. She drew the line there. Later, she reminisced about how affectionate the cat she and Ray had adopted had beenhe slept 'right up against your face.' In other words, one level of physical intimacy was considered acceptable with a dog and a different level acceptable with a cat.

3.21 I observed that she had never been as close to the other pets and she told me how Ray had made the observation-'A dog will give back if you invest in the relationship. It's a real relationship.' She already had three children when she took on my dog, her brother's dog, and adopted Linus the cat. Not only did she not have the emotional need or resources to invest in relationships with them, those particular pets lacked the capacity for that kind intimacy. Her brother's dog was 'a dufus' and she diplomatically avoided listing the shortcomings of my dog. When Posy died, Carmen had a paw print made and a few months later took her children and one of my sons down to the creek where we had spent so many happy hours with our dogs, to scatter her ashes. She does not plan on having another dog until she has an empty nest.

\section{Intimacy with Natal Family}

3.22 One of the ways SMCs sometimes manage the demands of parenthood in the absence of a spouse is by means of close relationships with their natal family. Carmen's relations with her natal family, though close, are not always unambiguously supportive. During the years I have known her, relations with her family have fluctuated-at times they are warm and supportive; other times family fissures emerged.

3.23 When we skyped for this essay, Carmen had just returned from a successful three-week visit with her mother, brothers and their families. The brother with whom she'd had a falling out, had recently had his first child, and during this visit, he patched things up and had Carmen and her children over for dinner and brought his baby over to play with its cousins and to ask Carmen for childcare advice.

3.24 Carmen also took her children to a toy store owned by a paternal cousin. 'That was great, that was also family, because he looks just like my father.' The children never got a chance to meet their grandfather, who died before their birth, and they kept asking, "'He looks like grandpa? Really? Does he look like grandpa?' It was really important, as we live in the middle of nowhere, to have an opportunity for those kinds of connections."

3.25 The visit was also an important bonding time for the children with their grandmother. While Carmen dealt with her real estate, her mother had lots of time alone with the children. 'They loved it, to the point where when she almost joined us back here this trip.' Carmen hoped one of her brothers would fly her mother out for an extended stay in the spring (which he did) as 'She is good company for me. Another adult to talk with, another [kind] of intimacy I would really welcome.' She believes that her willingness (even eagerness) to have her Mom come live with them 'is directly related to my single status. My grandmother's moving in with my parents directly contributed to the divorce of my parents, according to my father, who resented it all his life.' She speculates that her Mom's presence in her home would 'dampen most romantic options with a man' and 'wonders if there's a correlation between elderly parents in the home and the amount of sex enjoyed by married couples.'

3.26 Another intimate family activity is eating. Bianchi et al.'s time study found that one of the ways women are able to work more and spend equal or more time with their children is by reducing the amount of time they spend eating. That rang true for Carmen. She takes a lunch to eat at her desk. In the evenings, she sits at the table for grace, but then is up while the children eat, 'to pour milk and, you know, I'll do things I shouldn't be doing like unloading the dishwasher or starting cleaning the lunchboxes for the lunches the next day, ' and once they are done and have left the table to begin music practice, she eats what is left on their plates. If her mother is present, when she sits down to 'eat clean up', her mother has always saved for her 'the best chunk of her salmon or something.'

3.27 During the period of conflict with her younger brother and relations had chilled between Carmen and her mother as a result, Carmen reached out to her oldest brother Ted, who had had a troubled relationship with their mother on and off since his teenage years. Carmen started having regular, long phone conversations with him. 'He was very relieved to have understanding from within the family.' Carmen describes these talks as 'a very maturing process for me. It helped me separate from my mom, become an adult.' She talks to him at least once a week, and sometimes multiple times a day. She consults him on every major decision. 'He is a CPA, an attorney, 
a landlord, a parent. Kind of better than a husband. We talk about parenting, money, the rest of our family.' She believes that the camaraderie they share, because of their common childhood, knowledge of their father 'who was so hard to know,' and their ethnic heritage, is something he doesn't have with his wife or his daughters. She gave the example of telling each other Korean-accent jokes which no one else would get.

\section{Intimate Friendships}

3.28 The nature and importance of friendships is a topic of interest to sociologists of intimacy (Budgeon 2006, Jamieson et al 2006). According to Jamieson (1998:76), scholars are divided about whether adult friendships have become more or less important during the decades that have seen increasing divorce rates and a greater value has been placed on 'disclosing intimacy.' One school of thought is that friendships diminished in importance during the ascendance of the companionate marriage and then, in recent years, have become more important as marriages have become fragile. ${ }^{[7]}$ According to this view, friendship would be expected to be a particularly important category of personal relationship for someone like Carmen, who does not have a partner with whom to confide and narrate the self. Empirical studies, like those of Bianchi et al. (2006: 105), found that single mothers do indeed spend more time with friends and relatives than married mothers and fathers. Even with a $25 \%$ diminution in the number of hours per week single mothers spent with family and friends between 1975-2000 (from 19 to 14 hours per week), they still spend more time doing so than married adults do (10 per week throughout this time period) (2006: 105).

3.29 Carmen reported several changes in the way she views and experiences friendships since she became an SMC. Because she is a single parent and does not have a co-parent to share her concerns with, 'my friendships are more important. I am conscious that I don't want to burden my kids with my problems.' But when she started to describe the friendships she had made in her new home town, it became evident that her intensive single parenthood has made forming new friendships more difficult. One reason is simply the lack of time and energy.

I am in this vortex of childcare and career, and everything else you know, I just, the emotional space in my life doesn't feel like it is generous.

3.30 Understandably, the issues on her mind concern the everyday challenges of raising three youngsters, e.g., how long it was taking her to potty train her son. 'It does seem like a lot of my conversations are about me and my situation. So sometimes I feel like I can't talk about, you know, earrings or normal girl talk,' something in the past she always enjoyed. She told me about a conversation she had had with a colleague that morning walking in from the car to the elevator and the effort it took for her to steer herself away from talking about her kids or her mom. In the past, she never felt it took such an effort to focus on other people.

3.31 As the interview continued it became clear that there were other ways her single motherhood posed a challenge for intimate friendships with colleagues.

It is risky. For me to complain about how hard it is at home is basically saying, 'You know, I'll delay my tenure clock.', or, 'She must not be publishing as much as she should.', 'How does she find time to write or program or plan for classes?' So that is an impediment to friendship. I need to guard, to conceal.

3.32 It is not just from colleagues that she tries to conceal the challenges she faces as an SMC:

because they are judgmental and particularly with other women who are married, who made other choices than I. They want to see signs of strain, I feel, to comfort themselves, to help justify their decisions.

She reminds me that one of the reasons she had been reluctant to take this job is because of what a small community it is. She would have preferred a 'large city where there would be a fairly separate home experience and a very separate work experience and I could control the interactivity between those spheres.' Yet, she finds socializing is easier at home.

I try to invite families with kids, because it is easier for everybody - it's a play-friendly home, we have a yard, we have the upstairs, we have the three playmates.

Whether or not to trust people enough to welcome them into her home was a recurring theme in our discussions. Carmen recalled how growing up poor had been an impediment to forging friendships.

our family was rough. There was a lot of fighting, we had a cement floor... My mother was so ashamed of that, so I was also ashamed of it. She called it 'the chicken coop.' I wasn't going to invite my friends over who lived in these beautiful suburban cul de sacs with BMW's.

She noted, 
Like Stendahl (1925), she sees 'trust' as the determining factor in whether or not a friend is considered 'an intimate. '[8]

\title{
A Feeling of Intimacy at Korean Church
}

3.33 Carmen's father was a lapsed Catholic and Carmen's mother's family had been converted to Christianity by American missionaries in Korea. Until the divorce, though, the family did not attend church. After the split, her father started attending a Unitarian Church and her mother started attending a Korean United Church of Christ. Carmen alternated weekends and churchgoing accordingly.

3.34 When Carmen moved to the Midwest, she discovered that there was a United Methodist Korean Language church and, after much consideration, since she is not a believer, decided to join as a way of providing her children with exposure to their maternal ethnic heritage and for all the benefits such a community can offer. Indeed, this dimension of Korean churches is one of the explanations why Christianity is so popular among Korean-Americans. Between $70 \%$ and $80 \%$ of Korean-Americans are Christians. There are an estimated 4,000 Korean-Language churches in the United States in contrast to 89 Korean Buddhist temples. These churches are primarily liberal protestant denominations, which, happily for Carmen, have been relatively open to and supportive of SMCS, tending to judge their choice based on motive and consequences (Bock 2000:80).

3.35 The church has proven to be a very important part of Carmen's family life - they attend Sunday service and stay for the Korean lunch after, she makes regular donations and organizes the craft activities for Sunday School.

3.36 She feels very 'at home' at church. One time, over lunch, the men and women from her Bible group told her, 'We perceive you to be [one of us.]' She responded,

\begin{abstract}
It feels intimate to me to come to church. I don't have to be on my best behavior or fake it. I can relax in a way I can't even in American culture sometimes. I understand what's going on with their interaction with my kids. It is intimate for them too, in a way. Yes, the food, the humor, the banter, the judgmentalness, the competitiveness, even the nature of the spirituality is familiar. I mean, I do not love every aspect of it, I know they judge me. They said, 'Don't you feel like [we] are judgmental and I said, 'Yes, Koreans are among the most judgmental people I've ever met and I've lived all over the world,' and they said asked, 'So do you feel that at church?' and I said, 'Yes, but I accept that. What can I do, kill myself?'
\end{abstract}

She concluded that this is a dimension of 'intimacy- a sort of social communal sense.'

\section{Other SMC-related spaces for intimacy}

3.37 Carmen suggested relations with infertility doctors and relations with donor siblings as two possible sites for intimacy particular to being an SMC. The doctor Carmen and her SMC friend Norma had used had recently died. 'We have this $21^{\text {st }}$ century intimacy with him. It is not romantic. It's not biological, obviously, but he feels in some weird way like a part of our family.' She went on to say that after his death she read his blog which...

'made me realize that I did not know him at all. I literally had like three meetings with him, because his staff did everything. I didn't know about his issues with his son, his upbringing as an immigrant son or how he felt about his work.'

3.38 Other families created with sperm from the same donor are another potential source for intimate relations. Norma and her two children were planning to meet some of their donor-siblings, but Carmen reported that 'at this point' she is not 'open' to doing this with/for her children but recognizes that her feelings may change when her children are teenagers, if they initiate it, as Norma's teenagers did. 


\title{
A Changing Landscape of Intimacy
}

4.1 Several weeks after our initial interviews, Carmen emailed me with her current thinking about the topic of heterosexual intimacy.

\begin{abstract}
I'm drifting towards the idea that intimacy with a man is suitable for ANY TIME BUT the phase of life when babies, young children and raising them is in play. Don't studies show that these are the most vulnerable times for married couples? When they're most at risk of splitting up? No time for each other, tug-of-war \& compromise regarding raising the kids, dumpy bodies from no exercise and round the clock work... It strikes me that intimacy between men and women would be most successful before and/or after this particularly stressful, fraught phase.
\end{abstract}

Carmen's vision of heterosexual intimacy resembles what psychologist Finkel (2014) and her coinvestigators call 'the all-or-nothing marriage.' They argue that Americans today 'can achieve an unprecedentedly high level of marital quality - but only if they are able to invest a great deal of time and energy in their partnership.' In other words, if and when marital partners can engage in what one might call 'intensive coupling,' akin to 'intensive parenting,' they can achieve marital happiness unprecedented in previous generations. To do so, at the same time as being devoted to careers and intensive parenting, is well-nigh impossible, whereas to do so sequentially, as Carmen contemplates, may afford a life which includes intimacy with both a companionate sexual partner and with children.

4.3 As I suggested in the introduction, the case of SMCs illustrates how greater gender equality, resulting from public policy, not interpersonal negotiation, is enabling some heterosexual women to forgo heterosexual intimacy during the childrearing years and to concentrate instead on forging and maintaining intimate relations with others-most especially, but not exclusively, with their children. Carmen credits feminism with her ability to become a mother this way. Despite the accusations of some, choosing to form a family without a 'daddy' does not make one a 'man-hater.' Carmen posits a life during which intimate relations with men (and dogs) are enjoyed before and after but not during the childrearing years. Heterosexual intimacy is deprivieleged as the most important form of intimacy; it is one of many forms of physical and emotional intimacy heterosexual women can enjoy.

4.4 What Carmen's case portrays is not only a landscape of intimacy that changes from one period of life to another, but also the broader social changes which have transformed the social terrain on/through which Americans like Carmen can forge their intimate landscape.

4.5 Social commentaries which seek to explain recent changes in married and family life, do so based on a comparison of statistical snapshots. My study suggests that a life-course approach reveals a more complex picture of these emerging family forms. [9]Further, I suggest that the trope of landscape works especially well for capturing both the dynamism of an individuals' intimate life and the process by which the depiction of such is created. To conclude, I return to the Hockney landscapes that inspired my thinking on these matters.

4.6 In a book of essays, 'David Hockney: A Bigger Exhibition,' published in conjunction with a Hockney retrospective, Weschler describes Hockney's drive to 'widen his vantage' and the many techniques he developed in his quest to achieve 'a bigger picture,' to be able to 'depict the world as it is actually experienced' (Weschler 2013:29). One of these techniques, that of 'reverse perspective,' is employed in the Hockney's 'Garrowby Hill' (1998) reproduced here (Figure 3). In this painting, Weschler observes, Hockney layers 'space upon space,' stacks 'horizon upon horizon' (2013:30). This is what I have tried to do in this depiction of Carmen's intimate landscape.

4.7 Another technique he used in his landscape paintings of 2005, is 'of mounting multiple canvases on easels, one beside the next...creating vitas that were not just bigger and wider, but that featured multiple overlapping vanishing points, pulling the viewer ever more actively into the scene' (Weschler 2013:35). The technique for producing these 'combines' - setting up canvases side by side - is not unlike the technique Carmen and I have used, working side by side, in crafting this essay. Though the final product, like Hockney's combines, is recognizable as a single landscape, it profits from the wider vantage that comes from working together, from similar, but still inevitably different points of view.

\section{Acknowledgements}


The research for this piece was supported by the National Science Foundation. The views expressed do not necessarily represent those of the Foundation. I profited enormously from the detailed suggestions of three anonymous reviewers and the two editors. As always, my profound thanks go to Carmen for her friendship and for sharing Maria, Nel, Toby, and Posy with us and to GJ Barker-Benfield, my intimate partner, thanks to whom my work is always enriched.

\section{Notes}

Carmen selected the pseudonyms used in this study. For more on details on her upbringing see (Layne 2013b, 2014).

Clarke and Ayres (2013) suggest a causal relationship between post-Title IX women's participation in sports and greater 'independence from potentially patriarchal institutions' such as heterosexual marriage. They found that a $10 \%$ increase in female sports participation generated a $6 \%$ increase in the number of women who are single mothers.

This painting lends itself for such an interpretation, as can be seen in Ratmansky's 2014 New York City ballet based on it in which dancers representing the circles come together and move apart, reconfiguring themselves in a myriad of ways, expressing a wide range of feelings and moods.

Seventy-six percent of the 291 SMCs in Jadva et al.'s 2009 study had had long-term relationships and of these, $7.6 \%$ had been married. Of the 23 women in Graham's (2014b) study, 20 had had prior, long-term relationships od which two were marriages; four of the 26 SMCs in Bock's 2000 study had been married. All had assumed that they would become mothers in 'a long-term, stable relationship.'

A similar sentiment was expressed by 13 of the 23 women in Graham's study (2014b:109) - they 'wouldn't have a relationship to work at as well as a new baby to look after.'

According to Gabb (2010:115), relationships with companion animals 'are typically excluded...from intimacy research.'

Friendships are the model for what Giddens calls the 'pure relationship,' a 'social relation entered into for its own sake, for what can be derived by each person from a sustained association with another; and which is continued only in so far as it is thought by both parties to deliver enough satisfactions for each individual to stay within it' (1992:58). According to Giddens, relations with spouses and kin have come to be more like friendships. One scholar of contemporary friendships suggests that friendships are of special significance during 'transitional stages of personal life, such as when a partner has not yet been found or has been lost' (Rawlins cited in Jamieson 1998:76).

Stendahl, reminiscing about his youth (circa 1800), describes his relationship with one school friend as 'intimate' because their friendship was 'founded upon perfect mutual confidence' (1955: 209-210).

Jamieson et al. (2006: 3.10) suggest that the concept of 'life-course' might be usefully deployed to study changing personal relationships that include relationships outside of the household, just as I have done here.

\section{References}

ABRAMS, T (1994) My Test-Tube Daddy. March. The Washingtonian.

AMERICAN ASSOCIATION OF UNIVERSITY WOMEN (2015) The Simple Truth about the Gender Pay Gap (Spring 2015) http://www.aauw.org/files/2015/02/The-Simple-Truth_Spring-2015.pdf.

ANGEL, M (2014) 'The Women at the Top' The New York Review of Books. p 18-21. March 20. 
ASKOWITZ, A (2008) My Miserable, Lonely, Lesbian Pregnancy. San Francisco: Cleis Press.

BENEFIELD, R, Weschler, L, Howgate, S, Hockney, D (2013)David Hockney: A Bigger Exhibition. Munich: Delmonico Books.

BERLANT, L (1998) 'Intimacy: A Special Issue' Critical Inquiry 24(2):281-288. [doi:10.1086/448875]

BEHAR, R (1993) Translated Woman: Crossing the Border with Esperanza's Story. Boston: Beacon Press.

BIANCHI, S M, Robinson, J P, Milkie, M A (2006)Changing Rhythms of American Family Life, New York: Sage.

BOCK, J D (2000) 'Doing the Right Thing: Single Mothers by Choice and the Struggle for Legitimacy'Gender \& Society 14(1): p. 62-86. [doi:10.1177/089124300014001005]

BODENHORN, B (nd) 'Fragments of intimacy and the reassembling of relations'

BOMEMAN, J and Hamoudi, A, eds. (2009) Being There: The Fieldwork Encounter and the Making of Truth. Berkeley: University of California Press.

BUDGEON, S 2006 Friendship and Formations of Sociality in Late Modernity: The Challenge of 'Post Traditional Intimacy' Sociological Research Online 11(3). [doi:10.5153/sro.1248]

COLEMAN, L (2009) The Obligation to Receive: The Countertransference, the Ethnographer, Protestants, and Proselytization in North India. In Bomeman and Hamoudi eds. Being There: The Fieldwork Encounter and the Making of Truth. Berkeley: University of California Press. p. 113-150.

[doi:10.1525/california/9780520257757.003.0005]

CLARKE, P, Ayres, I (2014) 'Girls rule, boys drool: The Chastain Effect: Using Title IX to Measure the Causal Effect of Participating in High School Sports on Adult Women's Social Lives' Journal of SocioEconomics. [doi:10.1016/j.socec.2013.11.001]

CRAPANZANO, V. Tuhami. A Portrait of a Moroccan University Of Chicago Press, Chicago / London 1980.

DREXLER, P (2005) Raising Boys without Men: How Maverick Moms are Creating the Next Generation of Exceptional Men. Rodale Press.

Eckel, S (2014) 'Feminism isn't ruining your love life: The media loves to crow that smart, liberated women are hopeless in romance. Actually, the opposite is true' Slate Tuesday, Jan 7, 2014 07:00 PM EST http://www.salon.com/2014/01/08/feminism_isnt_ruining_your_love_life/

EDIN, K and Kefalas, M (2007) Promises I Can Keep: Why Poor Women Put Motherhood Before Marriage. Berkeley: University of California Press.

FINKEL, E J (2014) 'The All-or-Nothing Marriage: Couples can be happier now than ever before. But it's rare.' New York Times Feb. 14. http://www.nytimes.com/2014/02/15/opinion/sunday/the-all-or-nothingmarriage.html?_r=0.

FISHEL, D (2010) Sperm Donor X: A Different ConceptionFilm. http://www.NewDayFilms.com

GABB, J (2010) Researching Intimacy in Families. London: Palgrave.

GIDDENS Anthony (1992) The Transformation of Intimacy: Sexuality, Love, and Eroticism in Modern Societies,Stanford: Stanford University Press.

GRAY, A 2006 "The Time Economy of Parenting" Sociological Research Online 11(3). [doi:10.5153/sro.1393]

GRAHAM S (2012) 'Choosing single motherhood? Single women negotiating the nuclear family ideal' in D. Cutas and S. Chan (eds.), Families - Beyond the Nuclear Ideal. London: Bloomsbury Academic.

GRAHAM S (2014a) 'Stories of an absent 'father': single women negotiating relatedness through donor profiles' in T. Freeman, F. Ebtehaj, S. Graham and M.P.M. Richards (eds.), Relatedness in Assisted Reproduction: Families, Origins, Identities. Cambridge University Press. [doi:10.1017/cbo9781139814737.015]

GRAHAM, S (2014b) Imagined Futures: Experiences and Decision-Making of Single Women Embarking upon 
Motherhood through Sperm Donation. Ph.D. Dissertation. Cambridge University.

HERTZ, R (2006) Single by Chance, Mothers by Choice: How Women are Choosing Parenthood without Marriage and Creating the New American Family. Oxford: Oxford University Press.

HOCKNEY, D 1998 Garrowby Hill, oil on canvas, 60x76 in.

http://www.hockneypictures.com/works_paintings_90.php

JACKSON, P (2013) Call for Papers Intimate Ecologies of Social Reproduction for a panel to be held at the annual meeting of the Cultural and Political Ecology Specialty Group of the Association of American Geographers Tampa, April 8 -12, 2014

JADVA, V, Badger, S, Morrisette, M, and Golombok, S (2009) "Mom by choice, single by life's circumstance...' Findings from a large-scale survey of the experiences of single mothers by choice', Human fertility, 12 , p.175-84. [doi:10.3109/14647270903373867]

JAMIESON, L (1998) Intimacy: Personal Relationships in Modern Societies. London: Polity Press.

JAMIESON, L (1999) Intimacy Transformed? A Critical Look at the 'Pure Relationship' Sociology 33(3):477-494.

JAMIESON, L (2011) "Intimacy as a Concept: Explaining Social Change in the Context of Globalisation or Another form of Ethnocentrism" Sociological Research Online 16(4)15.

http://www.socresonline.org.uk/16/4/15.html [doi:10.5153/sro.2497]

JAMIESON, L. (2006). Intimacy. In A. Harrington, B. Marshall, \& H. Muller (Eds.),The Routledge Encyclopedia of Social Theory, Routledge.

LAYNE, LL (1996) "How's the Baby Doing?': Struggling with Narratives of Progress in a Neonatal Intensive Care Unit', Medical Anthropology Quarterly 10(4):624-656. [doi:10.1525/maq.1996.10.4.02a00130]

LAYNE, LL (2010) 'Donors and Daddies, Fathers and Lovers: The Presence of (Mostly) Absent Men in Narratives of Single Mothers by Choice', Phoebe: Gender \& Cultural Critiques21(2):1-20.

LAYNE, LL (2013a) 'Creepy,' 'Freaky,' and 'Strange': How the 'Uncanny' can Illuminate the Experience of Single Mothers by Choice and Lesbian Couples who Buy Dad. 'Journal of Consumer Culture14 (2), July. [doi:10.1177/1469540513482600]

LAYNE, LL (2013b) 'Intensive Parenting Alone: Negotiating the Cultural Contradictions of Motherhood as a Single Mother by Choice' in (Eds.) Faircloth, Hoffman and Layne. Parenting in Global Perspective: Negotiating Ideologies of Kinship, Self and Politics. p. 213-228. Routledge.

LAYNE, LL (2014) "I have a fear of really screwing it up': The Fears, Doubts, Anxieties, and Judgments in the Experience of One American Single Mother by Choice" Journal of Family Issues. LAYNE, LL, Graham, S (2013) 'That's Selfish': Moral Judgments by and about Single Mothers by Choice in the US and UK' Workshop on The Rhetoric of Selfishness and Selflessness, Cambridge University, June.

MACVARISH, (2006) What is the Problem' of Singleness? Sociological Research Online, Volume 11, Issue 3 , http://www.socresonline.org.uk/11/3/macvarish.html.

MATTES, J (1994) Single Mothers by Choice: A Guidebook for Single Women Who are Considering or Have Chosen Motherhood. New York: Random House.

MORRISETTE, Mikki (2008) Choosing Single Motherhood: The Thinking Woman's Guide. Boston: Houghton Mifflin.

MURRAY, C, Golombok, S (2005a) 'Going it alone: Solo mothers and their infants conceived by donor insemination', American Journal of Orthopsychiatry, 2, p. 242-253 [doi:10.1037/0002-9432.75.2.242]

MURRAY, C, Golombok, S (2005b) 'Solo mothers and their donor insemination infants: follow up at age 2 years', Human Reproduction, 20, p. 1655-1660. [doi:10.1093/humrep/deh823]

NATIONAL CENTER FOR SCIENCE AND ENGINEERING STATISTICShttp://www.nsf.gov/statistics/sed/2012

NATIONAL SCIENCE FOUNDATION (2013) 'Doctorate Recipients from U.S. Universities: 2012' Arlington, VA (NSF 14-305) I December 2013 http://www.nsf.gov/statistics/sed/2012/pdf/tab14.pdf. 
NATIONAL SCIENCE FOUNDATION (2014) National Center for Science and Engineering Statistics, NSF/NIH/ED/USDA/NEH/NASA Survey of Earned Doctorates; special tabulation (February 2014).

http://en.wikipedia.org/wiki/Pell_Grant

http://en.wikipedia.org/wiki/Higher_Education_Act_of_1965

RADIN, P (ed.) [1926] 1983 Crashing Thunder: The autobiography of an American Indian.Lincoln: University of Nebraska Press.

RICHARDS, M P M (2014) 'A British history of collaborative reproduction and the rise of the genetic connection.' In (Eds.) Freeman ,F, Ebtehaj, F, Graham, S, Richards, M. Relatedness in Assisted Reproduction. Families, Origins and Identities. Cambridge: Cambridge University Press. [doi:10.1017/cbo9781139814737.003]

ROSENEIL, S 2006 "On Not Living with a Partner: Unpicking Coupledom and Cohabitation"Sociological Research Online 11 (3) http://www.socresonline.org.uk/11/3/roseneil.html.

RUDAVSKY, 0 and J Katz 2000 And Baby Makes Two. Video.

SCHAMA, S 1995 Landscape and Memory. New York: Vintage Books.

SEARLE, A (2012) David Hockney landscapes: The wold is not enough. A review of Hockney's exhibit "A Bigger Picture" at the Royal Academy in London." The Guardian.

http://www.theguardian.com/artanddesign/2012/jan/16/david-hockney-landscapes.

SHOSTAK, M (1983) Nisa: The Life and Words of a !Kung Woman(New York: First Vintage Books.

SIMMONS, L W (ed.) 1945 Sun Chief: The Autobiography of a Hopi Indian. New Haven: Yale University Press.

SLOAN, Louise (2007) Knock Yourself up: no man? No problem!: A Tell-All Guide to becoming a Single Mom.New York: Avery.

SMITH, M F (1954) Babo of Karo: A Woman of the Muslim Hausa New Haven: Yale University Press.

SOISETH, Aleaxandra (2008) Choosing You: Deciding to Have a Baby on My Own. Berkeley, CA: Seal Press.

STENDAHL [1925] 1955 The Life of Henri Brulard. Translated Catherine Alison Phillips. New York: Vintage.

STONESIFER, Jene (1994) When Baby Makes Two: Single Mothers by Chance or by Choice.Los Angeles: Lowell House.

WALVIN, J (2013) Crossings: Africa, The Americas and the Atlantic Slave Trade London: Reaktion Books.

WESTON, K (2012) The Intimacy of Resources: A three-part public lecture series, Department of Social Anthropology, Cambridge University. 